\author{
Matgorzata Tryuk (D) \\ Uniwersytet Warszawski \\ m.tryuk@uw.edu.pl
}

\title{
„Potem przemówił komendant Brygady naszej tow. Hiszpan w języku niemieckim i tow. kapt. tłumaczyl"
}

\author{
Tłumaczenie w Brygadach Międzynarodowych \\ podczas wojny domowej w Hiszpanii 1936-1939
}

\section{Wstęp}

W Archiwum Akt Nowych (AAN) w Warszawie w zbiorze dokumentów dotyczących XIII Międzynarodowej Brygady im. Jarosława Dąbrowskiego z czasów wojny domowej w Hiszpanii z lat 1936-1939¹ znajdują się trzy cienkie zeszyty zapisane ołówkiem lub piórem, gęstym, równym pismem, i zatytułowane „Pamiętnik Bobrusia”" . Jego autorem był Boruch Nysenbaum, młody warszawski komunista, zwany też Bobrusiem. Do

\footnotetext{
Archiwum Akt Nowych - AAN, Zespół 182.

2 AAN, Zespół 182/VII-9 „Wojna Domowa w Hiszpanii - Pamiętnik Bobrusia”. O pamiętniku tym pisze Zofia Szleyen w maszynopisie złożonym prawdopodobnie w Archiwum KC PZPR, zatytułowanym „Bobruś (1912-1937)”.
} 
1989 roku dokumenty były przechowywane w Centralnym Archiwum KC PZPR (a konkretnie w Archiwum Zakładu Historii Partii) i były niedostępne szerszej publiczności. Część dokumentów dotyczących wojny domowej w Hiszpanii znajduje się także w Archiwum Żydowskiego Instytutu Historycznego w Warszawie ${ }^{3}$.

„Pamiętnik Bobrusia” jest wyjątkowym dokumentem historycznym na temat polskiego udziału w wojnie domowej w Hiszpanii. Jest subiektywnym przekazem zdarzeń, świadectwem bezgranicznego zaangażowania w sprawę Republiki hiszpańskiej i oddania ideologii komunizmu. Pamiętnik ten posiada dodatkową wartość dla historyka przekładu, gdyż ukazuje, jak - w tej wielojęzycznej sytuacji, współczesnej wieży Babel odbywała się komunikacja między ochotnikami, którzy przybyli na apel Republiki z całego prawie świata, oraz między nimi a miejscową hiszpańską ludnością.

\section{Tłumaczenie w Brygadach Międzynarodowych}

Kwestia języka i tłumaczenia podczas konfliktów zbrojnych jest dziś jednym z bardziej rozwijanych tematów przez historyków przekładu. Można nawet stwierdzić, że wojna i thumaczenie są nierozłącznie powiązane, gdyż potrzeby są ogromne, a znaczenie języka jest nie do przecenienia. Nic dziwnego, że problem ten podejmowany jest przez licznych badaczy [por. np. Baigorri Jalón 2018, 2020a i b; Footitt i Kelly 2012a i b; Tryuk 2012]. Popyt na thumaczy w rejonach dotkniętych wojną lub konfliktami zbrojnymi znacznie przewyższa podaż. Liczba wykształconych thumaczy, czy są to cywile, czy też wojskowi, jest często niewystarczająca. Z kolei rekrutowanie miejscowych pośredników językowych obciążone jest ryzykiem, że okażą się oni nielojalni wobec hierarchii wojskowej lub że będą niekompetentni. Stąd też konieczność kształcenia tłumaczy wojskowych, którzy towarzyszą armiom podczas działań wojennych. Szkolenie tłumaczy wojennych ma dosyć bogatą tradycję i zostało już wielokrotnie opisane w literaturze [np. Ždanova 2009; Kieslich 2016, 2018], w pracach, które analizują systemy kształcenia tłumaczy podczas II wojny światowej na potrzeby Armii Czerwonej oraz Wehrmachtu.

W latach 1936-1939 w odpowiedzi na apel Komunistycznej Partii Hiszpanii, w obronie Republiki, przybyli ochotnicy z 53 krajów, często bez znajomości języków obcych, zatem bez znajomości języka hiszpańskiego.

3 Żydowski Instytut Historyczny - ŻIH, sygn. 332. 
Międzynarodowy wymiar wojny domowej musiał mieć bezpośredni wpływ na sytuację językową w Brygadach, w których znaleźli się robotnicy, działacze komunistyczni i związkowi, socjaliści, anarchiści, republikanie i antyfaszyści z Francji, Belgii, Wielkiej Brytanii, Niemiec, Austrii, Włoch, Polski, Holandii, Węgier, Czechosłowacji, Bułgarii, z krajów bałkańskich, a także z USA, Kanady, Australii, Meksyku, Argentyny. W sumie do Hiszpanii przybyło około 35 tys. ochotników. Przyjmuje się, że w Brygadach Międzynarodowych walczyło też około 4,5-5 tys. Polaków, z czego większość stanowili polscy emigranci zarobkowi z Francji i Belgii, w większości działacze lub sympatycy Francuskiej Partii Komunistycznej. Szacuje się, że bezpośrednio z Polski przybyło do Hiszpanii około 600800 osób, według innych opracowań było ich 1200 [Pietrzak 2016: 65]. Najwięcej Polaków walczyło w szeregach XIII Brygady im. Jarosława Dąbrowskiego, która brała udział w większości kluczowych operacji wojny, pod Guadalajarą, w walkach o Brunete i w bitwie nad Ebro, na froncie aragońskim.

Systematyczne badania nad komunikacją językową podczas wojny domowej w Hiszpanii są prowadzone od niedawna ${ }^{4}$. Powszechnie uważa się, iż wykwalifikowani tłumacze nie brali w niej udziału. Jednak hiszpański historyk Ricardo Miralles [por. Serrano Velázquez 2012] podaje, iż wraz z dwoma tysiącami radzieckich „doradców”, ZSRR wysłało do Hiszpanii grupę 70 tłumaczy, którzy mieli za zadanie umożliwić komunikację między hiszpańskimi lojalistami a doradcami radzieckimi. Rodríguez-Espinosa [2020] podaje jednak, że do Hiszpanii łącznie przybyło 204 tłumaczy. Wśród nich były siostry Adelina i Paulina Abramson [por. Baigorri Jalón 2018]. W kwaterze głównej Brygad Międzynarodowych w Albacete dla radzieckich i międzynarodowych dowódców tłumaczyli m.in. Amerykanin John Victor Murra (Izak Lipszyc) [por. Baigorri Jalón 2020], Rosjanki Maria Levina i Elizavieta Parszina oraz Hiszpan Luis Abollado Varga, działacz Juventudes Socialistas Unificadas [Rodríguez-Espinosa 2020], Australijka Aileen Palmer [Kölbl 2020], Irene Falcon, Maria Fortus, Ilse Kulcsar, Constancia de la Mora, Lise Ricol i Lydia Kuper [Rodríguez-Espinosa 2016], Marina Ginestà i Regina Citron [Wolf 2020]. Tłumacze byli potrzebni także w Madrycie, gdzie koncentrowały się działania

\footnotetext{
$4 \quad$ Owocem jednego z takich badań jest baza tłumaczy opracowana przez zespół z Uniwersytetu w Graz, dostępna pod adresem https://gams.uni-graz.at/context:iiw, dostęp 3.01.2021.
} 
propagandowe, mieściły się redakcje gazet republikańskich, przebywali zagraniczni dziennikarze itd. [Baigori Jalón 2021; Kölbl 2021].

Aby sprostać potrzebom komunikacji językowej w Brygadach Międzynarodowych, stosowano rozmaite rozwiązania mające na celu porozumienie się między ochotnikami oraz między nimi a ludnością lokalną [por. Baigorri Jalón 2018, 2019a i b]. Przede wszystkim tworzone były jednostki narodowe złożone z ochotników mówiących tym samym językiem, np. XIII Brygada im. Jarosława Dąbrowskiego. Innym rozwiązaniem było używanie jednego wspólnego języka znanego większości ochotników. W kompanii im. Naftalego Botwina językiem tym był jidysz, a w 129. Brygadzie czesko-bałkańskiej, w skład której wchodzili przedstawiciele kilkudziesięciu narodowości, środkiem komunikacji był rosyjski [Ochotnicy Wolności: 386; Baigorri Jalón 2018, 2021]. Trzecim rozwiązaniem było wykorzystywanie thumaczy ad hoc. Aleksander Szurek „Alek”, komisarz polityczny w XIV Brygadzie im. Marsylianki (La Marseillaise) dowodzonej przez generała Karola Świerczewskiego „Waltera”, w której byli ochotnicy 32 narodowości, wspomina: „Trzeba było znać francuski, angielski, niemiecki i Bóg wie jaki jeszcze język [...]. Generał [Świerczewski] z języków obcych znał trochę francuski, pomagał mu szofer Włoch, ja znałem niemiecki i jakoś to szło" [Ochotnicy Wolności: 231]. Generał „Walter” przemawiał jednak najczęściej po polsku, o czym świadczy poniższe wspomnienie interbrygadzisty Mieczysława Szleyena ${ }^{5}$ :

Wybaczcie mi towarzysze Hiszpanie, że nie będę mówił po hiszpańsku, ale od dłuższego czasu mam po raz pierwszy sposobność przemawiać w języku polskim, który jest moim językiem ojczystym [Ochotnicy Wolności: 267].

Polscy ochotnicy z Francji i Belgii znali język francuski i można przypuszczać, że mieli mniejsze trudności w porozumiewaniu się z miejscową ludnością. Do Hiszpanii przybywali także działacze komunistyczni, którzy znali języki obce. Na przykład Salomon Jaszuński „Justyn”, którego wspomina Szleyen, był absolwentem studiów filozoficznych na Uniwersytecie Jagiellońskim, „wybitnym lingwistą i poliglotą znającym kilkanaście języków" [Ochotnicy Wolności: 367]. Latem 1937 roku do Hiszpanii

$5 \quad$ Mieczysław Szleyen (1905-1955), polski komunista, redaktor gazetek frontowych Dąbrowszczak i Ochotnik Wolności.

6 Salomon Jaszuński (1902-1938), zastępca komisarza politycznego Brygady im. Jarosława Dąbrowskiego. Zginął w bitwie nad Ebro. 
przybyła za swoim mężem Mieczysławem Zofia Szleyen ${ }^{7}$, która została skierowana do pracy propagandowej w Komisariacie Politycznym Brygad Międzynarodowych, początkowo w Madrycie, a następnie w Barcelonie. Jej praca polegała na redagowaniu polskojęzycznych wydawnictw, głównie gazetek batalionowych Dąbrowszczak oraz Ochotnik Wolności. Tak wspomina swoje pierwsze zadanie thumaczeniowe:

Po krótkiej naradzie towarzysze ustalili, że będę sekretarką, maszynistką i thumaczką redakcji [Dąbrowszczaka]. Dano mi kilka słowników i kazano przetłumaczyć na razie jeden artykuł z hiszpańskiej gazety.

- Nie potrafię chyba...

- Musisz. Znasz francuski, łacinę. Masz słowniki.

- Nie umiem pisać na maszynie.

- Nie szkodzi. Nauczysz się w ciągu tygodnia. Nasi ochotnicy też nie umieją strzelać, a nie dostają więcej czasu na naukę.

Postanowiłam zasłużyć na miano ochotnika wolności oddając wszystkie siły tej pracy, która dla mnie była formą walki. Rzeczywiście po tygodniu stukałam już jako tako na maszynie, czytałam i wybierałam nadchodzące od dąbrowszczaków materiały, próbowałam rozumieć po hiszpańsku słuchając relacji przybywających z frontu żołnierzy. Od nich i od mieszkańców starej ulicy Velázquez [pod numerem 63 mieściła się redakcja Dąbrowszczaka] chroniących się w podziemiach metra przed bombardowaniem, „uczyłam się Hiszpanii" i uczyłam się kochać jej ludzi [Ochotnicy Wolności: 58-59].

Z początku ochotnicy przybywający z Polski do Hiszpanii nie odczuwali potrzeby znajomości języka hiszpańskiego w kontaktach z miejscową ludnością. Boruch Nysenbaum „Bobruś”, który wysyłał do gazetki batalionowej Dąbrowszczak swoje „Plotki”, pisze:

[...] nie rozumiemy naszych odmiennych języków, ale jak dobrze się jednak rozumiemy. Te stare Hiszpanki widzą, że z dalekiej Polski przyjechaliśmy tu bronić ich wolności, która jest także wolnością Polski ludowej [Ochotnicy Wolności: 119].

Inny ochotnik, Wiktor Mencel, we wspomnieniu „O młodym Hiszpanie Manuelu” zamieszcza następującą rozmowę:

\footnotetext{
7 Zofia Szleyen (1904-1994), po II wojnie światowej była thumaczką literatury hiszpańskiej i latynoamerykańskiej.
} 
- Manuelu, czemu nie uczysz towarzyszy polskich twego języka, jesteśmy przecież w Hiszpanii, ludzie powinni znać wasz język?

- Po co - mówi mi Manuel -i tak się rozumiemy [Ochotnicy Wolności: 171].

W swoich wspomnieniach ochotnicy podkreślają, że wszyscy mówią „wspólnym antyfaszystowskim językiem” [Ochotnicy Wolności: 172]. Jednak o potrzebie znajomości języka ludności miejscowej piszą gazetki batalionowe. I tak np. w numerze 2 Notre Combat (organu XV Brygady Międzynarodowej) z 6 marca 1937 znajduje się krótka notatka z „rozmówkami” francusko-hiszpańskimi:

5 minutes d'Espagnol

La rapidité de notre victoire dépend de la cohésion de notre armée républicaine et surtout de la liaison intime des forces antifascists internationals avec les forces populaire espagnoles. Chaque milicien international doit apprendre autant que possible l'Espagnol.

Nous voulons chaque jour, dans notre journal, l'aider dans sa tâche.

Pour aujourd'hui, apprenons ces deux phrases:

Pour dire - Je regrette de ne pas parler l'Espagnol.

Prononcer: Sièn-to no ablar el Espagnol.

Pour dire - Il ennuie à qui attend.

Prononcer: Kiène èspé-ra déséspéra ${ }^{8}$.

Przeważało jednak przekonanie, że znajomość języka hiszpańskiego nie jest potrzebna ochotnikom. Jak wspomina Chaim Poncz „B. Chari”: „który dąbrowszczak ma czas uczyć się po hiszpańsku?” [Ochotnicy Wolności: 158].

W Brygadach Międzynarodowych tłumaczenie miało miejsce przede wszystkim podczas rozmów na wysokim szczeblu, np. między radzieckimi doradcami i dowódcami Brygad a Hiszpanami, w trakcie działań wojennych oraz „na tyłach” frontu, np. podczas przekazywania rozkazów, w celach szpiegowskich i propagandowych, podczas procesów przed sądami wojennymi i powszechnymi, w szpitalach polowych, podczas przesłuchań jeńców wojennych, w więzieniach i w obozach, przy prowadzeniu cenzury i w końcu w kontaktach z ludnością miejscową [por. Baigorri Jalón 2018, 2019a i b]. Także we wspomnieniach polskich ochotników przeważa pogląd, że tłumaczenie było istotne przede wszystkim dla celów ideologicznych, podczas zgromadzeń, apeli, na wiecach, z okazji przemówień

${ }_{8}$ Archiwum ŻIH, sygn. 332. Pisownia oryginalna. 
komisarzy politycznych. W swoim wspomnieniu „Na przedpolach Saragossy" Mieczysław Szleyen tak opisuje wielojęzyczne zgromadzenie:

Po krótkim zagajeniu komisarza brygady, przemówił komisarz dywizji, towarzysz Vidal ${ }^{9}$. Przedstawił zebranym towarzyszom zadanie bojowe. Przemawiali towarzysze Rwal ${ }^{10}$, Stopczyk ${ }^{11}$, przedstawiciel Węgrów, Garcia - przedstawiciel hiszpańskiego Frontu Ludowego i jeszcze kilku towarzyszy hiszpańskich [Ochotnicy Wolności: 139].

W takiej sytuacji konieczne było tłumaczenie:

Oba przemówienia (tj. komisarza politycznego Stopczyka i towarzysza Rwala) thumaczy na język hiszpański towarzysz Wiktor ${ }^{12}$, redaktor „Dąbrowszczaka” i sekretarz komisarza brygady; przerywane są oklaskami i okrzykami [Ochotnicy Wolności: 141].

$\mathrm{Na}$ wiecach i apelach w charakterze tłumaczy występowali komisarze polityczni lub oficerowie informacyjni, ideologicznie przygotowani do tego typu wystąpień. Wspomniany już Aleksander Szurek, adiutant generała „Waltera”, tłumaczył wystąpienia i pogadanki propagandowe z rosyjskiego i polskiego na hiszpański. Zdarzyło się nawet, że tłumaczył przemowę Węgra Mihályego Szalvaia „Czapajewa”, dowódcy batalionu im. Rakosiego, chociaż nie znał języka węgierskiego [Szurek 1989: 251]. Paweł Iwanowicz wspomina: „Towarzysz komisarz przywitał nas bardzo gorąco i przez tłumacza powiedział te wzruszające słowa powitania" [Ochotnicy Wolności: 61].

W celach propagandowych publikowane były także wielojęzyczne wydania gazet. W swoim studium na temat Brygad Międzynarodowych Marcin Michcik [1950] podaje, że centralnym organem brygad, wydawanym w językach francuskim, niemieckim i angielskim, później i w innych, był Le Volontaire de la Liberté. Wydanie polskie miało na początku tytuł polski (Ochotnik Wolności), potem hiszpański (El Voluntario de la Libertad)

\footnotetext{
9 Joaquín Vidal Munárriz (1882-1939), jeden z dowódców Brygad Międzynarodowych, skazany na śmierć i rozstrzelany w 1939 roku.

10 Gustaw Reicher „Rwal” (1900-1938), przedstawiciel Komunistycznej Partii Polski przy Komunistycznej Partii Hiszpanii. W grudniu 1937 wezwany do Moskwy i aresztowany przez NKWD. We wrześniu 1938 skazany na śmierć z oskarżenia o szpiegostwo i stracony. Zrehabilitowany w 1955 roku.

11 Władysław Stopczyk „Ćwik”, komisarz polityczny XIII Brygady.

12 Seweryn Ajzner „Wiktor” (1914-1989), historyk i działacz komunistyczny.
} 
z dopiskiem po polsku: „wydanie polskie”. Do końca 1937 roku organem ochotników polskich było pismo Dąbrowszczak. W redakcji Dąbrowszczaka znaleźli się wspomniani wyżej Mieczysław Szleyen, Zofia Szleyen, Jan Wyka i Józef Mazel. Oprócz tych czasopism istniały jeszcze liczne gazetki oddziałowe, takie jak: Echo Szpitalne - gazetka rannych żołnierzy Słowian w szpitalu w Murcji; Za Wolność - gazetka okopowa batalionu im. Dąbrowskiego; Nasza Gazetka - organ kompanii ciężkich karabinów maszynowych im. Ludwika Waryńskiego; Attaque - organ 1 kompanii; Żotnierz Wolności - organ kompanii im. A. Mickiewicza; Nasz Maximegazetka polowa 4 kompanii ciężkich karabinów maszynowych batalionu im. J. Dąbrowskiego. Wydawana jest także gazetka Naprzód - pismo Batalionu im. José Palafoxa [Michcik 1950].

\section{3. „Pamiętnik Bobrusia”}

Na złożony w AAN pamiętnik Borucha Nysenbauma składają się luźne kartki oraz trzy ponumerowane zeszyty. Do zeszytu I dołączona jest osobna numerowana kartka (s. 1-2) zaczynająca się od słów: „Dziennik zacząłem pisać przed wyjazdem na front Huesca w Caspe". Zeszyt I (s. 1-15) zawiera relację z przygotowania do wyjazdu z Polski (od 14 grudnia 1936) i kolejne etapy podróży przez Bratysławę, Pragę, Wiedeń, Innsbruck, Szwajcarię. Pierwszy wpis z Hiszpanii nosi datę 8 czerwca 1937 i napisany jest w Caspe nad „Ebrą” (s. 16). Zeszyt I, liczący strony od 1 do 57, obejmuje okres od 8 czerwca do 1 lipca 1937. Zeszyt II, tj. strony 58-102, dotyczy okresu od 1 do 13 lipca 1937. Zeszyt III, strony 103-175, obejmuje okres od 13 do 28 lipca 1937. Ponadto dodane są luźne kartki numerowane od strony 176 do 210, obejmujące okres od 2 do 17 sierpnia 1937. Ostatnia notatka pisana jest we wtorek 17 sierpnia 1937 w „Eskorjalu”:

Po drodze do Madrytu śpiewalim. W mieście samym nas pięknie przywitali. Piękne jest to miasto, choć zbombardowane przez rok czasu. Naprawdę warto jest je bronić. Przed śpiewem zaprowadzili nas do koszar i tam częstowali nas piwem (jakie to smaczne) a potem mieliśmy jeszcze czas, to poszłem do szpitala aby odwiedzić naszych najdroższych, którzy zostali wyrwani z naszych szeregów. Z początku wchodzimy do holu (jest to były hotel, największy) piękny. Dużo rannych [Zeszyt III: 210].

Całość pamiętnika obejmuje niecałe 3 miesiące, od dnia przyjazdu do Hiszpanii do śmierci autora podczas bitwy o Saragossę. 
Życiorys Borucha Nysenbauma mógłby posłużyć za scenariusz niejednego filmu przygodowego lub sensacyjnego. Józef Mazel „Suliński”, towarzysz batalionowy Bobrusia, tak opisuje go w swoim wspomnieniu: „Dziecko robotniczej Warszawy, dziecko nędzy uliczek żydowskich, wstępuje do komunistycznej organizacji dziecięcej Pionier [...]. Wśród najlepszych Pioniera, którzy przechodzą do KZMP ${ }^{13}$, znajduje się i Bobruś" [Ochotnik Wolności: 351-353].

Boruch Nysenbaum pochodził $\mathrm{z}$ biednej żydowskiej rodziny $\mathrm{z}$ Warszawy. Pisze o sobie: ,ja, żydowski giser ${ }^{14} \mathrm{z}$ Warszawy” [Zeszyt II: 90]. Działacz Komunistycznego Związku Młodzieży Polskiej, organizuje w Warszawie strajki krawców, fryzjerów, metalowców. Wielokrotnie jest więziony (m.in. w więzieniu na Mokotowie w Warszawie, więzieniu we Wronkach, w Płońsku, w Pułtusku), o czym często pisze w swoim pamiętniku. Jako „niebezpieczny więzień” jest karany karcerem, izolatką, zakazem otrzymywania paczek. Przed wyjazdem do Hiszpanii sprawuje funkcję sekretarza Komitetu Dzielnicy Śródmieście KZMP. W grudniu 1936 wyjeżdża z Warszawy, by po pięciu miesiącach niebezpiecznej podróży, podczas której był wielokrotnie aresztowany i odstawiany z powrotem na polską granicę, dotrzeć do miejscowości Caspe nad rzeką Ebro w czerwcu 1937. Część jego drogi do Hiszpanii można odtworzyć na podstawie pamiętnika [Zeszyt I: 1-16]. Kolejne etapy jego podróży opisuje Józef Mazel:

Więzienie czeskie i austriackie, długie dni głodu i zimna w Wiedniu, noce spędzone na ławkach Prateru wiedeńskiego, 10 tygodni więzienia na granicy austriackiej, a potem śnieżne szczyty Alp na granicy austriacko-szwajcarskiej [...]. Droga Bobrusia trwająca 5 miesięcy należała do najcięższych [...]. Nie zapomnę nigdy jego młodzieńczej radości, gdy powiedziano mu w Paryżu, że będzie mógł od razu jechać dalej. Jeszcze dziś stoi mi przed oczyma skaczący z radości Bobruś, gdy po raz pierwszy ujrzał milicjantów hiszpańskich [Ochotnicy Wolności: 351-353].

Bobruś był ochotnikiem batalionu im. José Palafoxa, który wchodził w skład XIII Brygady Międzynarodowej im. Jarosława Dąbrowskiego. Oprócz Polaków w skład batalionu wchodzili Hiszpanie, Ukraińcy (w kompanii im. Tarasa Szewczenki) oraz Żydzi (w kompanii im.

\footnotetext{
13 Komunistyczny Związek Młodzieży Polskiej.

14 Odlewnik.
} 
Naftalego Botwina). Dowódcami batalionu byli kolejno Polak Jan Tkaczow $^{15}$, Hiszpanie Salvador oraz Fernando D'Haro i w ostatnim okresie Węgier - István Molnár. Komisarzami politycznymi byli Polacy i Hiszpanie, m.in. Bolesław Mołojec ${ }^{16}$ oraz Henryk Toruńczyk ${ }^{17}$.

W lipcu 1937 brygada pod dowództwem Józefa Strzelczyka „Jana Barwińskiego" walczyła pod Brunete, a w sierpniu na froncie aragońskim. W sierpniu 1937 do brygady włączono polską kompanię im. Adama Mickiewicza i wcielono ją jako 1 kompanię do Batalionu im. José Palafoxa. 8 sierpnia 1937 Brygada została przemianowana na XIII Brygadę Międzynarodową im. Jarosława Dąbrowskiego, a kompanię im. Adama Mickiewicza wydzielono z Batalionu im. José Palafoxa i przekształcono w polski 3 Batalion im. Adama Mickiewicza. W końcu sierpnia brygada walczyła pod Saragossą, gdzie wyróżniła się wypadem na miejscowość Villamayor de Gállego. W bitwie zginęło wielu bojowników, wśród zabitych był także Bobruś. Śmierć tego niespełna 25-letniego ochotnika datowana jest na dzień 23 lub 24 sierpnia $^{18}$. Piszą o nim jego towarzysze broni. W gazetce batalionowej Dąbrowszczak nr 48 z 4 października 1937 Józef Mazel zamieszcza o nim wspomnienie ${ }^{19}$. Pisze o nim także Stanisław Tomaszewicz ${ }^{20}$ [Ochotnicy Wolności: 154]. Nekrologi ukazują się również w żydowskiej gazetce Naje Folkscajtung w dniach 13-17 września $1937^{21}$.

15 Jan Tkaczow (1893-1938), kapitan Wojska Polskiego, działacz komunistyczny, major w Brygadach Międzynarodowych, dowódca batalionu im. J. Palafoxa, zginął w Estremadurze w 1938 roku.

16 Bolesław Mołojec (1909-1942), działacz Kominternu. Podczas wojny domowej w Hiszpanii dowódca brygady im. Jarosława Dąbrowskiego. Podczas II wojny pierwszy dowódca Gwardii Ludowej i I sekretarz Komitetu Centralnego PPR.

17 Henryk Toruńczyk (1909-1966), polski komunista i ochotnik w wojnie domowej w Hiszpanii. W 1938 roku był kolejno: adiutantem w batalionach im. J. Palafoxa i A. Mickiewicza, następnie szefem sztabu brygady.

18 Por. International Solidarity with the Spanish Republic 1936-1939 [1974], Progress Publishers, Moscow: 244-245.

19 Przedruk w: Ochotnicy Wolności: 351-353.

20 Pseudonim komisarza politycznego batalionu Mikołaja Dwornikowa (1907-1937), białoruskiego komunisty.

${ }^{21} \dot{Z} I H$, sygn. 332/23, s. 4. 


\section{Bobruś w Brygadach Międzynarodowych}

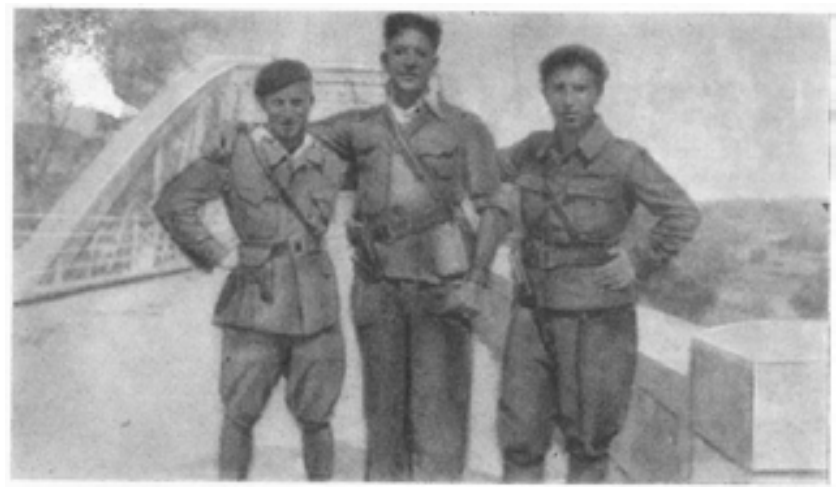

Fot. 1. Na moście na rzece Ebro. Pośrodku stoi Bobruś [Ochotnicy Wolności: 351]

„Pamiętnik Bobrusia” obejmuje okres od 8 czerwca do 17 sierpnia 1937, czyli niecałe 3 miesiące. Bobruś pisze prostą, nieporadną, niepoprawną polszczyzną, pełną zwrotów w jidysz. Na kolejnych kartach barwnie i z talentem opisuje życie w batalionie: czekanie, ćwiczenia w strzelaniu, przejazd na front, walkę i pierwszy widok trupów, przerzucanie jednostek na kolejny front, ofensywę. Sporo miejsca poświęca dyscyplinie wojskowej i przykładom jej łamania, m.in. zwraca uwagę na pijaństwo wśród ochotników. Opisuje liczne konflikty, np. z dowództwem na temat wyboru patrona batalionu, co wywołało niezadowolenie wśród ochotników z Polski; pisze o ,wewnętrznym” życiu batalionu. W ostatnim zeszycie, tuż przed bitwą pod Saragossą, wspomina, że został dotkliwie pobity przez kolegów ze swej kompanii pod pretekstem „oczerniania ich”. Pisze o uzbrojeniu, wyposażeniu i umundurowaniu ochotników; o otrzymywanym żołdzie (200 peset) i wydatkach (m.in. chodzi do kina), kreśli sylwetki kolegów, opisuje ich poglądy polityczne i pochodzenie. Sporo miejsca zajmują kwestie ideologiczne. Nysenbaum wypowiada się krytycznie na temat ,zdrady” PPS-u i Bundu, pisze o trockistach w Barcelonie, o konfliktach partii z hiszpańskim związkiem zawodowym Unión General de Trabajadores (UGT). Bobruś bardzo tęskni za domem, za Warszawą oraz towarzyszami. Czeka na listy i martwi się, gdy te nie dochodzą, a jego własne są cenzurowane. Jego towarzysze w kraju wiedzą, że jest w Hiszpanii, lecz ojciec wciąż łudzi się, że syn pracuje w fabryce gdzieś za granicą 
i prosi o przysłanie pieniędzy do domu. Bobruś opisuje prowincje, miasta i miasteczka hiszpańskie, przez które przejeżdża lub o które jego kompania toczy walkę. Jest w Monzón i Barbastro w prowincji Huesca, w Tortosie nad Ebro, w wiosce Tembleque w prowincji Toledo, w Villafranca de Castillo i Villanueva del Pardillo, gdzie miał miejsce chrzest bojowy Batalionu im. José Palafoxa. Jedzie do Barcelony na pogrzeb towarzysza Bernarda Frejtkesa, jest w Madrycie i w Escorialu (ostatni wpis w pamiętniku). Zachwyca się krajobrazem, górami, morzem, pięknem miast i miasteczek hiszpańskich. Opisuje, jak z innymi ochotnikami spędza nieliczne wolne chwile (kąpiel w morzu, w rzece, spacery w miasteczkach, kino, rzadko kawiarnie czy restauracje). Wspomina walki o Madryt, Bilbao, Albacete, Toledo, Brunete. Ochotnicy dużo śpiewają, głównie pieśni republikańskie i rewolucyjne (po polsku, ,żydowsku”, rosyjsku, ukraińsku), a także piosenki ludowe, lokalne. W chwilach wytchnienia lub gdy czeka na kolejny wymarsz, pisze do gazetki batalionowej Dąbrowszczak. Henryk Toruńczyk robi mu zdjęcia.

W „Pamiętniku Bobrusia” znaleźć można liczne wzmianki na temat sposobów komunikowania się w samym batalionie oraz z ludnością hiszpańską. Jak wspomniano wyżej, w Brygadach najważniejsza była praca propagandowa. Dbali o nią komisarze polityczni, jak można się dowiedzieć z poniższych wpisów w „Pamiętniku”:

Wtorek 8.VI.1937

Potem przemówił komendant Brygady naszej tow. Hiszpan w języku niemieckim i tow. kapt. tłumaczył [Zeszyt I: 16].

Przemówił do nich polit. (Staszek) nie bardzo dobrze. On widać umie robić lepiej niż mówić. Tłumaczył to po Hiszp. Markowiec. Na koniec zaśpiewaliśmy „Międzynarodówkę” i potem „Dąbrowszczaka” [Zeszyt II: 70].

Wtorek 6.VII.37

Rozdali gazetkę Bryg. Dąbrowskiego w 3 językach Polskim, Francuskim i Hiszpańskim. Wstępny artykuł jest poświęcony naszej kompanji. Pisał to kom. Polit. Tow. Regler Gustaw ${ }^{22}$ [Zeszyt II: 72].

W lipcu 1937 zebrał się w Madrycie Kongres Pisarzy Antyfaszystów. Pisze o nim Nysenbaum:

22 Gustaw Regler (1898-1966), niemiecki pisarz, członek Brygad Międzynarodowych, komisarz polityczny XII Brygady, ciężko ranny w 1937 roku w bitwie pod Huescą. 
Wtorek 6.VII.37

W Madrycie odbywa się „Międzynarodowy Kongres Pisarzy”. I nasza komp. wysyłała delegację [...]. Przyznam, że chętnie bym chciał być na tym kongresie. Po pierwsze chciałbym zapoznać tych pisarzy. Jeszcze nigdy nie byłem na takim kongresie, a po drugie chciałbym widzieć Madryt [Zeszyt II: 73].

Bobruś na Kongres nie pojechał, ale już następnego dnia do batalionu przyjechali pisarze. Ich wizytę opisuje tak:

Środa 7.VII.1937

Zbliża się tow. Rwal i powiada do mnie „Jak się masz Bobrusiu! Patrz przyszła nas odwiedzić pisarka niemiecka Anna Segler ${ }^{23}$ ". Patrzę właśnie idzie jakaś kobieta (nie brzydka) w towarzystwie kilku mężczyzn. Powiadam do niego „Niebrzydka dziewucha!” a on na to „Za starsza dla ciebie. Ona już ma męża”. Dosyć głupio mi było. Żałuję że się tak wyraziłem. Chłopaki byli rozebrani zaczęli się szybko ubierać. Doleciał tow. kap. i mówi: „Bobruś zbieraj chłopaków i zaśpiewacie coś ładnego. Latanina, wtem zebrali się wszyscy i tow. kapitan przywitał ich w naszym imieniu. Było ich 3-ech. Ta tow. i jeden bardzo gruby zewnętrznie nie sympatyczny pisarz holenderski Rost $^{24}$. Nosił chusteczkę z czterema węzłami ubrana na głowie (niby przeciw gorącu) wyglądał jak „baba jaga”. Przecież mógł zdjąć to na te kilka minut. Robi wrażenie takiego, który siebie bardzo lubi i nie chce się krzywdzić (na pewno przez to jest taki gruby). Dziwi mnie, że taka „natura” może należeć do naszego obozu. I trzeci tow. bardzo sympatyczny brunet z podłużną twarzą w wojskowym mundurze, jest on pisarzem i żołnierzem batal. „Telemana”. Ta towarzyszka jest nap. sympatyczną, tylko mrugała oczami (widać ma chore oczy). Przemówiła Seger, że 2 lata temu założyli stronnictwo lewicowych pisarzy i rzyczyli sobie aby mogli następny kongres odbyć w Madrycie i czego właśnie dzisz dokonały ${ }^{25}$ (zacząłem klaskać, wszyscy za mną). Poza tem (prosiła abyśmy nie odpowiadali) oświadczyła w imieniu wszystkich, że czują się wśród nas o wiele lepiej aniżeli wśród tych pisarzy. Ona pragnie nas zapoznać i napisać coś o nas. Powiedziała „Jest kobietą, mam w domu dzieci do których mi tęskno, ale naprawdę jest jej bardzo trudno się z nami pożegnać" (oklaski). Rwal przetłumaczył to na polski. Potem Rwal opowiedział

23 W rzeczywistości chodzi o Annę Seghers (1900-1983), niemiecką pisarkę, która odwiedziła batalion po zakończeniu Kongresu.

24 Nico Rost (1896-1967), holenderski pisarz i dziennikarz antyfaszystowski.

25 Od 4 lipca 1937 odbywał się w Walencji II Międzynarodowy Kongres Obrońców Kultury. Notatka o Kongresie w Dąbrowszczaku nr 33 z 5 lipca 1937. 
mi o dwóch rodzajach pisarzach takich które ,pływają w przestworzach i nie widzą świata lub wszystko rozpatrują z punktu widzenia swojego biurka. Ale są i takie które nie uważają za degradację spuszczenie się do ludu itp.”. Do tych ostatnich zaliczał ich i wznosił okrzyk o jednolitym antyfaszystowskim współdziałaniu robot. chłopów, żołnierzów i inteligencji podchwytywany przez wszystkich. Na zakończenie zaśpiewałem z Kiepurą hymn „Dąbrowszczaka” (zresztą dość udanie) i potem „Krasny Fłot” i „My w Brygadzie”. Ukraińcy z Diemenczukiem zaśpiewali pieśni ukraińskie o komuniźmie. Rozeszlim się z okrzykiem. Przyrzekła napisać do naszej gazetki kompan. Potem tow. Rwal opowiadał nam, że ona napisała jedną książkę o walce Rybaków ${ }^{26}$ i przez to stała się głośną i dzisz zbiera się napisać coś o „Dąbrowszczakach”. Potem dodał, że ona mu kiedyś przysłała do więzienia dobre paczki. Domyślam się, że to musi być jego żona ${ }^{27}$. Gdyż wiadomo, że jego żona jest Niemka („Gazeta Polska" pisała o tem) a on sam to potwierdził i ona mu kiedyś przysyłała do więzienia paczki na pewno coś między nimi jest, zresztą co to za różnica, tylko tak sobie piszę, to co mi się nasunęło na głupiej myśli [Zeszyt II: 80-82].

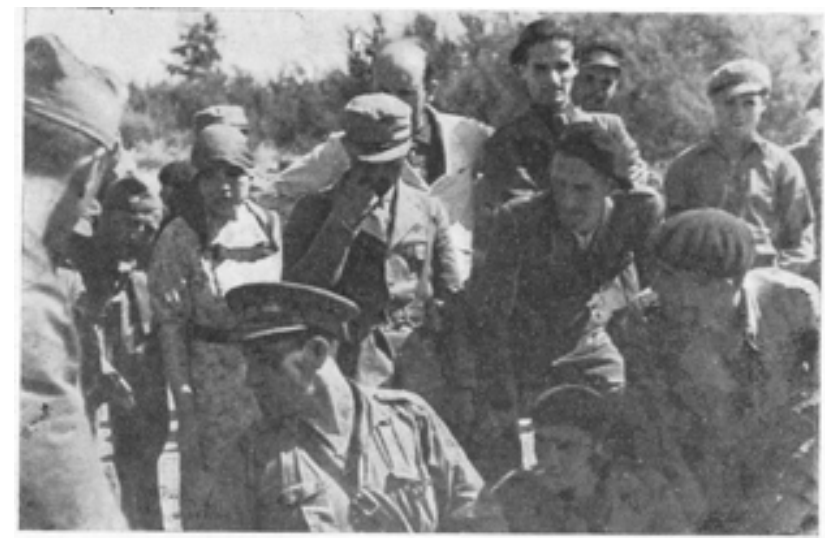

Fot. 2. Pisarze u brygadzistów. W chustce na głowie Anna Seghers, w berecie tow. Rwal [Ochotnicy Wolności: 387]

W pamiętniku sporo miejsca Bobruś poświęca lekturom, m.in. czyta powieść Czapajew Dmitrija Furmanowa, także powieści Uptona Sinclaira:

26 Aufstand der Fischer von St. Barbara (1928).

27 Żoną Gustawa Reichera była w rzeczywistości niemiecka komunistka Erna Harms. 


\section{Wtorek 20.VII.1937}

Czytałem kilka numerów „Noje Prese”. Opisuje tam jakiś Fesler, który był więziony u Franka, także pisze jakiś romans Uptona Sainklera ${ }^{28}$ „No pasaran" 29 . Nie podoba mi się ten romans, bo on (według mnie) nie jest prawdziwym odbiciem życia tutejszego, zresztą skąd on może je znać, kiedy tu go nie było, tylko jego bogata fantazja może to wszystko. [...] On nie zna prawdziwych ochotników, to jest fałsz, kłamstwo [Zeszyt III: 127-128].

Razem z Henrykiem Toruńczykiem „dyskutuje o krajowych poetach Tuwimie, Broniewskim itp." [Zeszyt I: 41], deklamuje wraz z towarzyszami wiersz Włodzimierza Majakowskiego Lewa marsz [Zeszyt II: 65]. Publikacja jego krótkich notatek w gazetkach okopowych zachęca go do poważnego myślenia o pisaniu:

\section{Czwartek 5 sierpnia 1937}

[chciałbym] abyśmy zwyciężyli jak najwcześniej, to wezmę urlop i zamknę się do chałupy na całe miesiące i będę pisał, pisał bez końca, a jak się zmęczę pisaniem to będę czytał, bo jeszcze nic prawie nie czytałem [Zeszyt III: 190].

Z ludnością cywilną Bobruś spotyka się w drodze na front, gdzie ochotnicy dowożeni są koleją lub ciężarówkami („kamionami”). Nie brakuje wtedy kontaktów:

Hiszpanie wznosili okrzyki: „E vinc la Pologne antifasista” ${ }^{30}$ [Zeszyt I: 44].

Napisałem w wagonie na ścianie co następuje: „Za naszą i waszą wolność”. Bat. Dąbrowskiego. Por Wuestra y Nuestra Libertado. Soldat. Polacos ${ }^{31}$ [Zeszyt I: 44].

Ochotnicy chętnie śpiewają po polsku, rosyjsku, najczęściej „Międzynarodówkę” i pieśń rewolucyjną „Krasny Fłot”, także po czesku, ukraińsku, włosku (np. „Avanti Popolo, Bandiera Rosa”), a najczęściej hymn brygady „Dąbrowszczaka" (nawet po hiszpańsku).

\footnotetext{
28 Chodzi o amerykańskiego pisarza Uptona Sinclaira.

29 No pasaran! A Novel of the Battle of Madrid.

30 Pisownia oryginalna.

31 Pisownia oryginalna.
} 
Wziąłem Kiepurę z jednej strony i Żurka Janka z drugiej strony i zaczęliśmy śpiewać monotonne pieśni i to tak mi po śmierci kochanego Bernarda ${ }^{32} \ldots$ usiedlim przy wodzie i z całego serca śpiewałem „Górala” w której jest tyle płaczu i tęsknoty. Aż przyszło do nas dużo Hiszpanów i chcąc nie chcąc musieliśmy zacząć śpiewać rewolucyjne pieśni [Zeszyt II: 80].

W pamiętniku notuje też kontakty z ludnością hiszpańską:

Wtorek 22.06.1937

Jedziemy dalej po godz. 1 po poł. jesteśmy w Taragonji. Długo staliśmy i chodząc po ulicy jedliśmy pomidory i wtem zauważyłem jak z pod na wpół zamkniętych okiennic wyglądają i śmieją się 2 ładne dziewczyny. Zbliżam się do nich a te zamiast - zwyczajem dziewcząt Madrygueras ${ }^{33}$ - uciekać stoją i się śmieją... Nawiązałem „rozmowę” i dobra jest. Byłem obrośnięty jak dziad, włosy rozczochrane, nieumyty z okopów, ubranie podarte, portki zerwane aż kolana widać było... A jednak doszłem, co się wstydzić? Ale pomyślałem, że nie trzeba się wcale krępować i mimo sprzeciwu tow. poprosiłem jej o igłę i nici celem zreperowania ubrania. Ona mi też chętnie dała 2 igły i rolkę nici. Ta młoda była najsympatyczniejsza i nareszcie zbliżyliśmy się na tyle, że jej dałem oglądać moich fotografii jednej chciała zabrać, ale nie chciałem dać. [...] Jak to niedobrze gdy się nie zna języka Hiszp. Nie można się porozumieć z nikim, jakbym chętnie z nimi porozumiał. Muszę nauczyć się po Hiszp.

[...] Gdy wyszedłem [po wizycie u fryzjera - MT] oczekiwali mnie wszyscy z wielką sympatią. Trochę jeszcze ,gadaliśmy” i pojechalim. Dość przyjemnie jest mieć znajomych i to w dodatku młodych, ładnych dziewcząt. Wieczorem jesteśmy w Tortosie [...]. Przepływa tam rzeka „Ebro” [Zeszyt I: 45-46].

Ochotników odwiedzają też miejscowi:

Kolacja. Przyszli Hiszpanie do nas i „gadamy” z nimi. Śpiewamy nasze pieśni [Zeszyt II: 82].

Sobota 3.VII.1937

[...] Hiszpanie krzyczeli „Wiw la Rusja”34. Mijamy pole obrabiane przez kolektyw chłopów. Podnoszą do góry sierpy, kapelusze, pięści na powitanie nas [Zeszyt II: 65].

32 Bernard Frejtkes „Bernard”, zginął pod Huescą w czerwcu 1937.

33 Pisownia oryginalna.

34 Pisownia oryginalna. 
Piątek 9 lipca 1937

Tak dobrze rozumiemy się bez słów [Zeszyt II: 91].

Jednak Nysembaum chce nauczyć się języka hiszpańskiego, o czym m.in. świadczy kartka ze słówkami hiszpańskimi z tytułem „Leccion segunda".

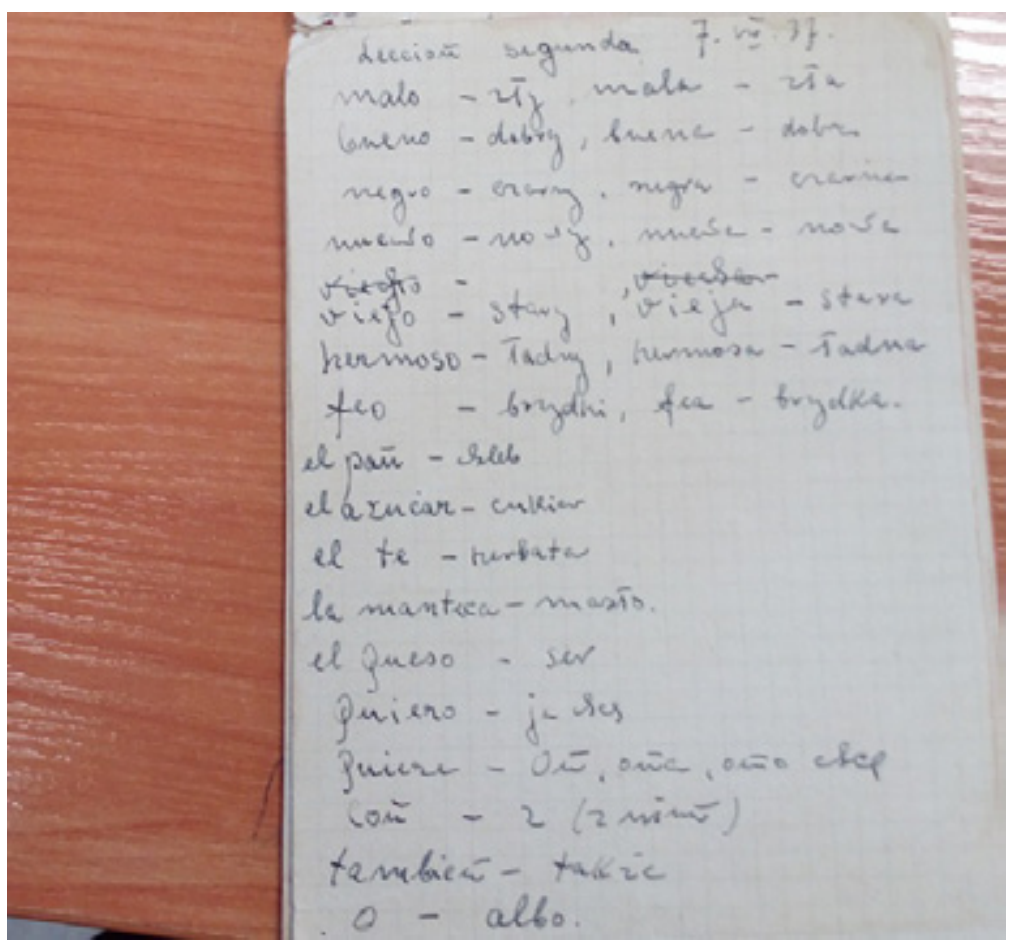

Fot. 3. Zeszyt III, s. 147 (zdjęcie autorki)

Dużo miejsca w pamiętniku zajmują plany na przyszłość po powrocie do kraju:

Sobota 12.6 .37

Dopiero tu widziałem okropności wojny. Oglądam zabitych. Coś naprawdę strasznego. Tak jestem zasadniczym przeciwnikiem wojny i właśnie biorę udział w wojnie tej aby raz na zawsze przezwyciężyć faszyzm i położyć kres 
źródłom wojen. Aby ludzie zamiast mordować się, zbratali się i żyli w zgodzie, gdyż świat jest naprawdę pięknym [Zeszyt I: 26].

Niektóre jego marzenia mają bardzo osobistą formę. Pisze:

Śniła mi się ładna dziewczyna i... ożeniłem się. Tak przyznam się potrzebowałbym naprawdę się ożenić. Ale co zrobić? Nie ma nawet czasu pomyśleć o tym [Zeszyt III: 187].

Więcej miejsca zajmuje polityka:

Jak bym chciał teraz być na mojej ukochanej dzielnicy „Śródmieście” chociaż dużo zdrowia straciłem przy tej dzielnicy, a może właśnie, że kosztowało mi dużo wysiłku. Co teraz wyrabiają komurki fryzjerów, jak się rozwijali? A jaki jest skład mojego K.D.? Kogo już aresztowali? Kto się jeszcze trzyma? A mój związek Metalowców? Moi mosiężnicy? Oni na pewno myślą, że już poległem, bo do nich nie piszę. Ach jak bym chciał być teraz $\mathrm{w} \mathrm{W}$-wie [Zeszyt II: 68].

My wszyscy chcielibyśmy wrócić do Polski i tam wykończyć swoich faszystów [Zeszyt III: 144].

\section{Podsumowanie}

Liczne zapiski z „Pamiętnika Bobrusia” przedstawiają sytuacje, które wymagały pośrednictwa tłumacza, a które mógł on bezpośrednio zaobserwować. Pierwsza $z$ nich dotyczy pracy propagandowej, tj. przy odczytywaniu odezw, proklamacji, w trakcie spotkań, wieców, podczas pogadanek politycznych. W takich sytuacjach thumaczyli zazwyczaj komisarze polityczni. Komisarze, działacze i lektorzy Kominternu mieli ideologiczne, a z czasem także językowe przygotowanie do wygłaszania, pisania, redagowania tekstów propagandowych. Gerszon Rotholc opisuje oficera informacyjnego Schönbacha, który nie znał hiszpańskiego, ale szybko się nauczył:

Schönbach opanował bardzo szybko język hiszpański. Wkrótce mógł już wygłosić po hiszpańsku referat o kwestii agrarnej w Hiszpanii. Mimo pewnych jeszcze trudności językowych wywołał swoim referatem bardzo wielkie zainteresowanie u towarzyszy hiszpańskich. Ciekawe były jego uwagi o położeniu chłopów w ZSRR. Po referacie otoczyli go towarzysze Hiszpanie i dziękowali 
mu. Towarzysz Schönbach cieszył się ogólną sympatią, ale szczególnie był lubiany przez towarzyszy Hiszpanów [Ochotnicy Wolności: 370].

Spontaniczne spotkania $\mathrm{z}$ ludnością lokalną, $\mathrm{z}$ hiszpańskimi ochotnikami, dziewczętami, dziećmi, starymi ludźmi były także okazją do rozwijania umiejętności tłumaczenia. Jednak w tych sytuacjach tłumacz nie był potrzebny, z ludnością cywilną ochotnicy ,gadali”, często śpiewali i to wystarczało dla skutecznej komunikacji między nimi. Bobruś uczył się słówek hiszpańskich, które mu pomagały w rozmowach z mieszkańcami:

Bardzo trudno nam się z miasteczkiem pożegnać, po pierwsze ze względu na bardzo przyjemne dziewczęta, które nas zamęczały, abyśmy z nimi tańczyli, i nie szczędziły komplementów jak np. „muy malo” (bardzo niedobry) [Ochotnicy Wolności: 117].

Choć „Pamiętnik Bobrusia” jest przede wszystkim zapisem jego udziału w wojnie domowej w Hiszpanii, stanowi jednocześnie wyjątkowy opis komunikowania się $\mathrm{w}$ rozmaitych sytuacjach w tych trudnych wojennych czasach, w których porozumienie się z miejscową ludnością było dla ochotników najważniejsze.

Dokument ten ma znaczenie dla historyków badających dzieje Polski w XX wieku. Historia polskich interbrygadzistów to ważny element historii i legendy polskiego komunizmu. W tę legendę wpisuje się „Pamiętnik Bobrusia". W polskim dyskursie politycznym i publicznym obecne są opinie krytycznie oceniające hiszpańskie zaangażowanie dąbrowszczaków, traktowanych jako wiernych ,żołnierzy Stalina”. Jak pisze Jacek Pietrzak [2016: 79], po wojnie zostali wykorzystani jako narzędzie propagandy i kształtowania nowej świadomości historycznej w pierwszych latach Polski Ludowej. Zapomniany bohater Brygad Międzynarodowych, Boruch Nysenbaum, Bobruś, młody idealista z Warszawy, zapisywał na gorąco swoje przeżycia, refleksje i obserwacje. Chciał, aby jego dziennik przeczytał w przyszłości historyk lub pisarz, który nada mu kształt literacki. Dzisiaj czytamy jego pamiętnik nie tylko jako unikalny dokument o czasach wojny domowej w Hiszpanii, lecz także jako źródło wiedzy o komunikacji międzykulturowej i międzyjęzykowej w tej wieży Babel, jaką były Brygady Międzynarodowe. 


\section{Bibliografia}

\section{Źródla archiwalne}

AAN - Archiwum Akt Nowych, Zespół 182/VII-9 „Wojna Domowa w Hiszpanii - Pamiętnik Bobrusia”.

Archiwum Żydowskiego Instytutu Historycznego, [Inwentarz zespołu], Wojna domowa w Hiszpanii 1936-1939, sygn. 332, oprac. M. Siek, Warszawa 2010.

\section{Źródla opublikowane}

Baigorri Jalón, J. (2018), „Intérpretes en la guerra civil española”, [online] https:// www.youtube.com/watch?v=RWlGNikO9T0, dostęp 2.05.2019.

Baigorri Jalón, J. (2019a), „Mambru vino a la guerra: las palabras nomadas de dos brigadistas internacionales en la guerra civil española (1936-1939). Marlborough came to war: the nomadic words of two international brigades' volunteers in the Spanish civil war (1936-1939)", [w:] Isidro Sánchez Sánchez, ed. Las Brigadas Internacionales, 80 años después, Instituto de Estudios Albacetenses „Don Juan Manuel” CEDOBI, Albacete: 95-123.

Baigorri Jalón, J. (2019b), Lenguas entre dos fuegos. Intérpretes en la Guerra Civil Española (1936-1939), Comares, Granada.

Baigorri Jalón, J. (2020), „The Interpreter Who Wanted to be a Rank-and-File Soldier: John Victor Murra", [w:] Julia Kölbl, Iryna Orlova, Michaela Wolf, Hg. ¿Pasaran? Kommunikation im Spanisch Bürgerkrieg. Interaction in the Spanish Civil War, New Academic Press, Wien: 100-113.

Baigorri Jalón, J. (2021), Languages in the Crossfire. Interpreters in the Spanish Civil War (1936-1939), Routledge, London, http://doi.org/10.4324/ 9781003145813.

Footitt, H., Kelly, M. (eds.) (2012a), Languages and the Military. Alliances, Occupation and Peace Building, Basingstoke, Hampshire, Palgrave Macmillan, https://doi.org/10.1057/9781137033086.

Footitt, H., Kelly, M. (eds.) (2012b), Languages at War. Policies and Practices of Language Contact in Conflict, Basingstoke, Hampshire, Palgrave Macmillan.

International Solidarity with the Spanish Republic 1936-1939 (1974), Moscow: Progress Publishers.

Kieslich, Ch. (2016), „Die Dolmetscher-Ausbildung in der Wehrmacht”, [w:] Dörte Andres, Julia Richter, Larisa Schippel, eds. Translation und 'Drittes Reich'. Menschen - Entscheidungen - Folgen, Frank \& Timme, Berlin: 121-141.

Kieslich, Ch. (2018), Dolmetschen im Nationalsozialismus. Die Reichsfachschaft für das Dolmetscherwesen, Frank \& Timme, Berlin. 
Kölbl, J. (2020), „Mädchen für alles? Aileen Palmer als Übersetzerin und Dolmetscherin in den medizinischen Einheinten des Spanischen Bügerkrieges", [w:] Julia Kölbl, Iryna Orlova, Michela Wolf, Hg. ¿Pasaran? Kommunikation im Spanisch Bürgerkrieg. Interaction in the Spanish Civil War, New Academic Press, Wien: 114-129.

Kölbl, J. (2021), The Babel of Tongues: Englischsprachige Freiwillige und ihr Beitrag zur Kommunikation im Spanischen Bürgerkrieg, LIT Verlag, Wien.

Kölbl, J., Orlova, I., Wolf, M., (Hg.) (2020), ¿Pasaran? Kommunikation im Spanisch Bürgerkrieg. Interaction in the Spanish Civil War, New Academic Press, Wien.

Michcik, M. (1950), „Polacy w Hiszpanii podczas wojny domowej”, Wiadomości. 02.04.1950, Londyn, [online] http://retropress.pl/wiadomosci/polacy-w-hiszpanii-podczas-wojny-domowej/, dostęp 17.04.2019.

Ochotnicy Wolności: księga wspomnień dąbrowszczaków (1957), zebrała, opracowała i opatrzyła słowem wiążącym Zofia Szleyen, Warszawa: Wiedza Powszechna.

Orlova, I. (2020), „Las etapas de la institualización de los/las interprétes en la guerra civil”, [w:] Julia Kölbl, Iryna Orlova, Michaela Wolf, Hg. ¿Pasaran? Kommunikation im Spanisch Bürgerkrieg. Interaction in the Spanish Civil War, New Academic Press, Wien: 180-193.

Pietrzak, J. (2016), „Polscy uczestnicy hiszpańskiej wojny domowej”. Acta Universitatis Lodziensis. Folia Historica. 97: 65-86, https://doi.org/10.18778/ 0208-6050.97.04.

Rodríguez-Espinosa, M. (2016), „;No Pasarán!: Translators under Siege and Ideological Control in the Spanish Civil War", Perspectives Studies in Translatology. 24(1): 22-35, https://doi.org/10.1080/0907676X.2015.1073765.

Rodríguez-Espinosa, M. (2020), „Undigging the Past: The Lost Memory of Interpreters at the Battle of Málaga 1936-1937”, [w:] Julia Kölbl, Iryna Orlova, Michaela Wolf, Hg. ¿Pasaran? Kommunikation im Spanisch Bürgerkrieg. Interaction in the Spanish Civil War, New Academic Press, Wien: 67-81.

Serrano Velázquez, M. (2012), „Traductoras rusas en la Guerra civil Espanola”, Rusia Hoy, [online] https://es.rbth.com/articles/2012/10/05/traductoras_rusas_en_la_guerra_civil_espanola_2051, dostęp 2.05.2019.

Szurek, A. (1989), The Shattered Dream, New York, Columbia University Press. Tryuk, M. (2012), 'Ty nic nie mów, ja będę ttumaczyt'. O etyce w ttumaczeniu ustnym, Warszawa: WLS.

Tryuk, M. (2020), „I Would Like to Speak Spanish. Memoirs of Boruch Nysenbaum", [w:] Julia Kölbl, Iryna Orlova, Michaela Wolf, Hg. ¿Pasaran? 
Kommunikation im Spanisch Bürgerkrieg. Interaction in the Spanish Civil War, New Academic Press, Wien: 32-48.

Wolf, M. (2020), „Sprachmittlung unter Spaniens Himmel: Fotografische Inszenierungen von Translation", [w:] Julia Kölbl, Iryna Orlova, Michaela Wolf, Hg. ¿Pasaran? Kommunikation im Spanisch Bürgerkrieg. Interaction in the Spanish Civil War, New Academic Press, Wien: 194-211.

Ždanova, V. (2009), Nasim oruziem bylo slovo. Perevodciki na vojnie. Unsere Waffe war das Wort. Translation in Kriegszeiten, Peter Lang, Frankfurt am Main.

\begin{abstract}
Abstrakt
Celem niniejszego artykułu jest opisanie wielojęzycznych interakcji w XIII Brygadzie Międzynarodowej im. Jarosława Dąbrowskiego według relacji Borucha Nysembauma, warszawskiego komunisty i bezpośredniego uczestnika hiszpańskiej wojny domowej. Jest to zarazem pierwsza prezentacja pisanych na gorąco pamiętników ochotnika, który nie wrócił $\mathrm{z}$ tej wojny. Autorka stara się odpowiedzieć na pytanie, w jaki sposób ochotnicy nieposiadający adekwatnych umiejętności w zakresie języków obcych porozumiewali się z hiszpańską ludnością i z towarzyszami broni, oraz omówić formy i specyfikę tej komunikacji.
\end{abstract}

Słowa kluczowe: tłumaczenie w strefach konfliktu, hiszpańska wojna domowa, Pamiętnik Bobrusia

\title{
Abstract \\ And Then the Commander of Our Brigade, Comrade Spanish, talked in German and Comrade Captain Interpreted. Interpretation in the Inter- national Brigades during the Civil War in Spain 1936-1939
}

The aim of the present article is to describe multilingual interactions at the XIII Jarosław Dąbrowski International Brigade between volunteers of different nationalities, mainly Poles, and the Spanish population as narrated by Boruch Nysembaum, a communist from Warsaw and a participant of the Spanish Civil War. At the same time, it is the first presentation of onthe-spot memoirs written by a volunteer who did not return from this war. On the basis of his narrative, the article tries to answer the questions concerning the way volunteers, who lacked adequate foreign language skills, communicated with the Spanish population and with other volunteers, the 
forms of their communications, and finally, the specific characteristics of this multilingual communication.

Keywords: interpreting in conflict zone, Spanish Civil War, The Memoirs of Boruch Nysenbaum 